\title{
Lumen
}

Selected Proceedings from the Canadian Society for Eighteenth-Century Studies

\section{À propos des auteurs About the Authors}

Volume 25, 2006

URI : https://id.erudit.org/iderudit/1012090ar

DOI : https://doi.org/10.7202/1012090ar

Aller au sommaire du numéro

Éditeur(s)

Canadian Society for Eighteenth-Century Studies / Société canadienne d'étude du dix-huitième siècle

ISSN

1209-3696 (imprimé)

1927-8284 (numérique)

Découvrir la revue

Citer ce document

(2006). À propos des auteurs / About the Authors. Lumen, 25, 253-256.

https://doi.org/10.7202/1012090ar

Copyright $@$ Canadian Society for Eighteenth-Century Studies / Société canadienne d'étude du dix-huitième siècle, 2006
Ce document est protégé par la loi sur le droit d'auteur. L'utilisation des services d'Érudit (y compris la reproduction) est assujettie à sa politique d'utilisation que vous pouvez consulter en ligne.

https://apropos.erudit.org/fr/usagers/politique-dutilisation/ 


\section{À propos des auteurs / About the Authors}

Jean-Luc Martine est Maître de conférences à l'Université de Bourgogne (Dijon) et membre de l'équipe Textes et édition. Il est l'auteur d'une thèse intitulée «Introduction à l'étude des métaphores de la machine dans la pensée de l'âge classique. L'idée de machine dans le discours des dictionnaires (1514-1798)", à paraître aux éditions Honoré Champion. Ses travaux portent sur l'histoire de la pensée classique $\left(\mathrm{XVII}^{\mathrm{e}}\right.$ et $\mathrm{XVIII}{ }^{\mathrm{e}}$ siècles), et particulièrement sur l'esthétique, les dictionnaires, les encyclopédies et l'œuvre de Diderot. Ses travaux de recherche s'orientent vers la presse savante, les cercles académiques et, plus largement, la formation, la circulation et la diffusion des concepts esthétiques.

Laura Benítez published El mundo en René Descartes, México: IIF, UNAM (1993), La idea de la historia en Carlos Sigüenza y Góngora, México: FFyL, UNAM (1982), and co-authored Espacio e infinito en la perspectiva de la modernidad, México: Edic. Cruz, 2000. She was President of the Asociación Filosófica de México, A. C. (1994-1996), and founding member of the Sociedad Latinoamericana de Historia de la Ciencia y la Tecnología (1982).

Marc-André Nadeau est doctorant en philosophie à l'Université d'Ottawa. Il prépare une thèse sur Montaigne et Rousseau dans laquelle il analyse et compare leur métaphysique, leur anthropologie et leur forme d'expression littéraire et philosophique à la lumière du scepticisme français.

Professeur de philosophie à la Faculté de théologie, d'éthique et de philosophie de l'Université de Sherbrooke, Sébastien Charles s'intéresse à l'épistémologie de l'âge classique. Il a fait paraître dernièrement sur ce sujet Berkeley au siècle des Lumières. Immatérialisme et scepticisme au XVIII siècle (Vrin, 2003), a dirigé un volume intitulé Épistémologie et science selon Berkeley (Presses de l'Université Laval, 2004) et, avec Marc André Bernier, a dirigé le recueil Scepticisme et modernité (Presses de l'Université de Saint-Étienne, 2005). 
Pam Perkins teaches eighteenth-century and Romantic literature at the University of Manitoba. She has edited Robert Bage's Hermsprong for Broadview Press and is currently working on a study of late eighteenthcentury Scottish women writers.

Codicologue de réputation internationale, Jacques $\mathrm{Ch}$. Lemaire enseigne la langue et la littérature du Moyen Âge à l'Université Charles de Gaulle (Lille III). Il s'intéresse aussi au XVIII siècle, en particulier aux rapports intellectuels entre les gens de lettres et la franc-maçonnerie. Il a publié 18 livres dont Mécanismes linguistiques de l'évolution sémantique en français, Introduction à la codicologie (1989), Vision de la vie de cour dans la littérature de la fin du Moyen Age (1994 - Prix de l'Académie Royale de Belgique), L'antimaçonnisme (1998), Evariste de Parny (2002), Le Complot judéo-maçonnique (2005, avec Alain Goldschläger), et a publié avec Raymond Trousson et Jeroom Vercruysse le Dictionnaire de Voltaire (1994).

Jay Macpherson retired in 1996 from teaching English at Victoria College, Toronto.

Guy Spielmann est enseignant-chercheur à Georgetown University (Washington). Spécialiste des arts du spectacle aux XVII ${ }^{\mathrm{e}}$ XVIII ${ }^{\mathrm{e}}$ siècles, particulièrement de la scénographie, du théâtre de foire et de la commedia dell'arte, il a publié de nombreux articles ainsi que Le Jeu de l'Ordre et du Chaos: Comédie et pouvoirs à la Fin de règne, 1673-1715 (Paris, Honoré Champion, 2002) et Parades: Le Mauvais Exemple, Léandre hongre, Léandre ambassadeur (Paris, Lampsaque, coll. «Le Studiolo-Théâtre», 2005). Il dirige OPSIS, centre virtuel de ressources sur les arts du spectacle aux $\mathrm{XVI}^{\mathrm{e}}$-XVIII ${ }^{\mathrm{e}}$ siècles (http://opsis.georgetown.edu).

Birte Giesler received her PhD from the University of Karlsruhe, Germany in 2001, and she is currently a lecturer at the University of Sydney, in Australia. Her research includes the motif of the artificial human being, contemporary drama, the German 'Bildungsroman,' the history of Germanic and literary studies, intertextuality, women and gender studies. She is the author of Literatursprïnge. Das erzählerische Werk von Friederike Helene Unger (2003), '. . . wir Menschen alle sind Palimpseste ...' Intertextuaalität in Hedwig Dohms 'Schicksale einer Seele' (2000), several articles on the 'Bildungsroman,' German women writers, and contemporary drama. She co-edited Gelegentlich: Brecht with Eva Korman, Ana Kugli, and Gaby Pailer (2004). 
Robert Eggleston is Associate Professor of English in the Faculty of Creative and Critical Studies at UBC Okanagan in Kelowna, BC. He has published articles and presented papers on various authors, including Jane Austen, H.E. Bates, Aphra Behn, John Cleland, Edward Ravenscroft, and Sir John Vanbrugh. His current research focuses on the comedies and farces of Edward Ravenscroft.

Noelle Gallagher is a doctoral student in the Department of English at the University of Chicago. She is currently completing a dissertation on early eighteenth-century British historical writing.

Nicholas Hudson, Professor of English at the University of British Columbia, is the author of Samuel Johnson and Eighteenth-Century Thought, Writing and European Thought, 1600-1830, Samuel Johnson and the Making of Modern England, and of many essays on eighteenth-century literature, thought, and culture.

Anne-Marie Link is Associate Professor of Art History at the Augustana Faculty, University of Alberta, Canada. She has published on the eighteenth-century print market and on the illustrated book, as well as on the discipline of art history in the eighteenth century. She is presently working on a book manuscript, Art, History, Museum and Discipline in the Eighteenth Century.

Jean-Jacques Tatin Gourier est professeur d'histoire des idées et de littérature du XVIII ${ }^{\mathrm{e}}$ siècle à l'Université François-Rabelais de Tours. Son travail porte sur la politique des Lumières. Il a notamment publié $L e$ Contrat social en question (PUL, I989), Lire les Lumières ( Dunod, 1997) et André Chénier, poésie et politique (Minerve, 2005, en collaboration avec Jean M. Goulemot).

Étudiante au doctorat en Lettres de l'Université du Québec à TroisRivières, Stéphanie Massé prépare actuellement une thèse sur le théâtre érotique clandestin dans la France des Lumières.

While he has always been fascinated by the entire 'long eighteenth-century,' Mark McDayter's personal research interests have tended to be focused on a period that might best be defined as 'the later Stuarts,' extending from the outbreak of the Civil War in 1642 to the Hanoverian Succession in 1714. Current projects include Rump: Or an Exact Collection. An Electronic Edition - a hypertext edition of an important early Restoration miscellany of Royalist verse satires; Indices to Seventeenth-Century Poetry; Writing Revolution: Seventeenth-Century Texts in the Benson Collections at the University of Western Ontario. 
Lisa M. Zeitz is Associate Professor of English at the University of Western Ontario. Current research interests include eighteenth-century British landscape gardens, and Restoration and eighteenth-century drama as re-imagined and revised by contemporary playwrights.

Marie-Hélène Chabut est professeur de littérature française à Lehigh University, en Pennsylvanie, où elle enseigne le XVIII ${ }^{e}$ siècle et l'écriture de femmes. Elle a publié sur Diderot de nombreux articles ainsi qu'un livre intitulé Denis Diderot. Extavagance et génialité (Rodopi, 1998). Depuis plusieurs années, elle a concentré sa recherche sur les femmes écrivains, en particulier Françoise de Graffigny et Isabelle de Charrière. Dans ses essais et publications sur Charrière, elle s'intéresse particulièrement à ses contes et nouvelles comme "écriture alternative" des Lumières. Récemment, elle a entrepris une analyse des personnages masculins qui subvertissent les critères de la masculinité contemporains de Charrière. 